https://doi.org/10.38129/Ann.Yur.Ist.2020.4.2.45

УДК 347.23(332.2):347.233: 347.233.5

\title{
АКСИОЛОГИЧЕСКИ-ИНСТИТУЦИОНАЛЬНОЕ РАЗВИТИЕ СБЕРЕЖЕНИЙ И ПРОБЛЕМА ЧАСТНОЙ СОБСТВЕННОСТИ В УСЛОВИЯХ СТАНОВЛЕНИЯ РЫНОЧНОЙ ЭКОНОМИКИ
}

\author{
ЮЛИЯ ГАВРИЛЬЧЕНКО (Минск, Беларусь) *
}

Развитие рыночных отношений дает мощный стимул для становления сберегательной культуры и права частной собственности. В литературе даже отмечается, что «отношения частной собственности появились в результате формирования рыночного хозяйства, в связи с необходимостью осуществить обмен произведенными продуктами» ${ }^{1}$. Это крайне спорное утверждение интересно тем, что оно отражает влияние капитализма на формирование современного понимания собственности и сбережений: «Здесь и начали формироваться «собственники», в дальнейшем распространившие идею присвоения далеко за рамки произведенного ими продукта»2.

Можно согласиться, что понятие частной собственности обретает современное значение вместе с распространением идеи «естественного права». По этой теории, выдвинутой английскими философами XVII в., а затем французскими просветителями XVIII в., право собственности объявляется прирожденным, данным от природы свойством, присущим всякому ${ }^{3}$. В условиях такой свободы права частной собственности сбережения получают возможность многовекторного развития, сберегательное дело и сберегательное право стремительно эволюционируют.

Вместе с тем, сам сберегательный процесс видоизменяется гораздо раньше уже в период зарождения капитализма. С развитием рыночных отношений сбережения постепенно обретают новое качество. Они начинают использоваться в инвестиционном процессе, могут предназначаться для покупки в будущем средств производства, а не просто потребления. Это

\footnotetext{
${ }^{1}$ Батурин В.С., Смелова Е.В. История становления и развития понятия собственности / В.С. Батурин, Е.В. Смелова // Вестник КарГУ. Серия «История». - 2012. - №1. - С. 106. 2 Там же.

3 Там же. С. 106-107.
} 
переломный момент, поскольку с появлением инвестиционного аспекта общесоциальная значимость сбережений становится бесспорной. Они больше не «окаменевают» в виде сокровища, а становятся источником увеличения будущего общественного богатства, стимулом развития экономики и фундаментом процветания государства.

Уже св. Фома Аквинский отличает простую ссуду от помещения капитала и объявляет наживу от первой недопустимой, а от второго - дозволительной.

В. Зомбарт отмечает, что «у Антонина Флорентийского и у Бернарда Сиенского понятие капитала развито до полной ясности и обозначается словом «капитал». Тому, что они умели сказать о нем, экономическая наука снова научилась только с Марксом» 4 .

Взаимное дополнение рационального мышления и христианских ценностей в определенной степени характеризует католический религиозный тип мышления. Можно согласиться, что, католическое учение (в отличие от православия) ставит перед человеком задачу преображения земного мира, прежде всего социальных отношений, на христианских началах и в значительной степени связывает ее с делом спасения 5 . Подобное преображение подразумевает построение общества не только основанного на гуманистических традициях, но и благополучного.

Катализатором развития сберегательной культуры становится протестантизм. М. Вебер относит бережливость к исходным чертам «капиталистического духа», закрепленного в протестантской этике. Идеальный тип капиталиста, к которому приближаются некоторые немецкие промышленники того времени, М. Вебер обозначает так: «Ему чужды показная роскошь и расточительство, упоение властью, ему присущ аскетический образ жизни, сдержанность и скромность» 6. Это - так называемая «философия скупости».

Протестантизм, особенно в кальвинистской версии, принято считать предтечей капиталистической идеологии. В кальвинизме всякое рациональное приобретательство поощряется, иррациональное использование и

4 Зомбарт В. Буржуа. Этюды по истории духовного развития современного экономического человека / В. Зомбарт : пер. с нем; Изд. подгот. : Ю.Н. Давыдов, В.В. Сапов. - М. : Наука, 1994. - С. 190.

5 Коваль Т.Б. Личность и собственность в христианстве: Православие. Католицизм. Простентантизм. Сравнительный анализ: дис. ... докт. истор. наук: 07.00.03 / Т.Б. Коваль. - Москва : Ин-т Европы РАН, 2009. - С. 278.

${ }^{6}$ Вебер М. Избранные произведения / М. Вебер : пер. с нем. - М. : Прогресс, 1990. - С. 141. 
неумеренность осуждаются. Основной добродетелью признается бережливость, граничащая со скаредностью (parvificentia), которую раньше считали тяжким грехом. Добродетель «великолепия» (magnificentia), воспетая средневековыми богословами, воспринимается кальвинистами как абсурдная идея.

В.Зомбарт утверждает, что бережливость как черта человеческого характера окончательно сформировалась в XIV в. в Италии и была распространена только среди делового мира. «К принципу «не расходовать больше, чем имеешь дохода», присоединился высший: расходовать меньше, чем имеешь дохода: копить. Идея сбережения явилась в мир!» 7 . Это высказывание не совсем обоснованно, поскольку склонность к сбережениям в различных ее проявлениях всегда была свойством человеческой натуры. Вместе с тем, именно в период зарождения капитализма, когда сбережения обретают общесоииальную иенность, бережливость становится положительным качеством, характеризуюшим человека.

В. Зомбарт объясняет становление капитализма ростом склонности к сбережениям. Он считает, что в развитии бережливости заключается величайшая заслуга кальвинизма перед капитализмом, «поскольку в нем живет мещанский дух»8. Тем не менее, вопрос о том, повлияла бережливость на развитие капитализма или капитализм определил становление сберегательной традиции, вряд ми имеет однозначный ответ; дисскуссии о первичности бытия или сознания не угасают на протяжение многих веков. При этом взаимосвязь мещанского мировоззрения и мещанского поведения остается бесспорной.

Мещанский тип монетарного поведения впервые опредяет Л. Б. Альберти и впоследствии детально анализирует В. Зомбарт: «Как смертельного врага остерегайся излишних расходов!» 9 . Так называемый сеньоральный тип монетарного поведения, когда сам разговор о деньгах считался неприличным, сменяется рационализацией ведения хозяйства.

T. А. Попова отмечает, что элементы мещанского типа монетарного поведения можно встретить довольно часто и в настоящее время. При этом она полагает, что главным фактором формирования данного типа поведения в современных условиях является низкий уровень жизни населения ${ }^{10}$.

7 Зомбарт В. Буржуа. Этюды по истории духовного развития современного экономического человека / В. Зомбарт : пер. с нем; Изд. подгот. : Ю.Н. Давыдов, В.В. Сапов. - М. : Наука, 1994. - С. 6.

8 Там же. С. 198.

9 Там же. С. 187.

10 Попова Т.А. Специифика экономического поведения человека $\mathrm{b}$ сфрере образования сбережений : дис. ... к. соииол. н : 22.00.03 / Т.А. Попова. - Курск : Курск. гос. техн. ун-т, 2003. - С. 28. 
Полагаем, это утверждение характерно скорее для славянского или «восточного» типа мышления. Применительно к современной западноевропейской цивилизации принципы бережливости и рационального ведения хозяйства, являющиеся основой мещанского типа монетарного поведения, до сих пор представляют неотъемлемый элемент, едва ли не одну из основ культуры. Это не в последнюю очередь связано с непрерывным поступательным развитием западноевропейского общества и, соответственно, сохранением сберегательной традиции.

На белорусских и украинских землях смешиваются западная и восточная культуры, а христианская традиция представлена во всем многообразии, соседствуя с другими конфрессиями и атеизмом. В результате, у нас можно встретить элементы как сеньорального, так и мещанского типа монетарного мировоззрения. Например, не только в дореволюиионный период, но даже $b$ настоящее время сохраняется определенная экономическая разница между хозяйствами западной и восточной Беларуси. В народе говорят, что «западники» более домовитые и, как результат, более зажиточные. Что касается восточных белорусских земель, то здесь более сильным оказывается Влияние восточной культуры (в широком понимании) и православия. «Иоанновское» христианство, по сути, стало преимущественно аскетически-эсхатологическим. «Оно утверждается, с одной стороны, на раскрытии духовной жизни через аскетическое усилие, направленное к спасению души, и, с другой, в связи с этим, на приготовлении к смерти и будущей жизни, «царству небесному»11.

М. Ф. Антонов, анализируя специфику российской экономической мысли, приводит слова И. В. Киреевского: «Роскошь проникала в Россию, но как зараза от соседей»12. Подобное высказывание любопытно тем, что представляет собой идеализацию, построенную на образе православного христианина.

На белорусских и украинских землях бережливость как продолжение рациональности связана, среди прочего, с распространенностью католицизма $и$ протестантизма. Несмотря на ряд библейских ограничений, католический религчозный тип, который часто связывают с именем апостола Петра, в иелом отражает идею деятельной, а не созерцательной земной жизни.

Протестантизм как реформационное движение проявился на наших землях в формах лютеранства, кальвинизма и арианства (антитринитаризма). При этом лютеранство широкого отклика среди населения не нашло.

11 Булгаков С. Апокалипсис Иоанна / С. Булгаков. - М. : Православное Братство Трезвости, «Отрада и Утешение», 1991. - С. 302.

12 Антонов М.Ф. Ложные маяки и вечные истины. Пути выхода страны из кризиса и русская общественная мысль / М.Ф. Антонов. - М. : Современник. 1991. - С. 43. 
Кальвинизм, напротив, в определенный период (преимущественно в XVI в.) был достаточно распространен. В Великом княжестве Литовском его представителями являлись А. Волан, Л. Сапега, Николай Радзивилл Черный и др. Идеи кальвинизма, попавшие на богатую культурную почву, во многом способствовали созданию выдающихся памятников средневекового права Статутов 1529, 1566 и 1588 гг.

Законодатель Великого княжества Литовского XVI в. отличает такие имущественные права, как собственность, владение («держание»), залог, сервитуты ${ }^{13}$. Во всех источниках права Великого княжества Литовского (привилеях, Статутах, др.) значительное внимание уделяется становлению права собственности и его защите.

Вместе с тем, показная роскошь осуждается. Например, мужчинам-евреям из украшений дозволялось носить на руках только по одному перстню: «Жидове 3 ланцухами и с клейноты золотыми ходити, так тех серебра на пасех, на кордех, на шаблях носити не мають. Вед же однак сыгнет на палщу один и перстень один кождому з них мети и жидовкам перстни, поес и уберы водлуг преможенья своего носити волно» (apm. 8 p. ХІІ Cmamyma 1588 г. ${ }^{14}$ ). А. Волан, подчеркивая в своих трудах особую связь между правом, моралью и справедливостью, критикует духовенство за то, что оно выставляет напоказ свое богаство ${ }^{15}$.

В развитии отечественной сберегательно-правовой мысли можно выделить также учения, отвергающие собственность как источник сочиальных конфликтов. Например, в середине 60-х гг. XVI в., в результате раскола в кальвинистском движении, появляется радикальное направление протестантизма - арианство (антитринитаризм). Представители левого крыла данного религиозного учения (М. Чаховиц, П. Гезка и др.) утверждают, что истинный христианин вообще не должен иметь собственности. Л. Крышковский в своей книге «Предисловие» выступает против частной собственности как причины всех бед. Он полагает, что человек верующий не должен желать богатства.

В конце XVI - начале XVII вв. можно наблюдать, с одной стороны, победу контрреформации и возврат позиций католицизма на Западе. С другой становление Российской империи с ее претензиями на геополитическое

13 Доутнар Т.І. Гісторыя дзяржавы і права Беларусі: падручнік / Т.І. Доўнар. - Мінск : Адукацыя і выхаванне, 2014. - С. 137.

14 Статут Вялікага княства Літоускага 1588 г.: тэксты, даведнік, каментарыі. - Мінск : Беларуская савецкая энцыклопедія, 1989. - 573 с.

15 Волян А. Аб грамадзянскай, або палітычнай съабодзе. Пераклад 3 лацінскай Ул. Шатона. - Мінск: Выдавец Зміцер Колас, 2009. - С. 14-23. 
первенство на Востоке. Это порождает конкуренцию и противодействие между двумя типами христианской изивилизаиии.

Ряд религиозно-политических деятелей предлагает в качестве компромисса концепцию конструктивного взаимопроникновения культур. В контексте сберегательного поведения она проявляется в нейтральном отношении к самим сбережениям, но осуждении чрезмерного богатства, скупости и т. п. Так, Симеон Полоцкий в своих «Стихах» пишет: «Сребролюбцы, зрите, а от сребра ко богу любовь обратите... Честь есть достойна всечестно живущим, а не богатство велика имущим. Добродетелей бог в людех смотряет, а не богатства, еже исчезает...»16.

Идея синтеза западной и восточнохристианской культур не получает должного развития. В первую очередь это связано с разделами Речи Посполитой $(1772,1793$ и 1795 гг.) и переходом белорусских и украинских земель к Российской империи, после чего начинается этап расширения православной христианской традиции. В контексте развития сбережений это в значительной степени означает возврат к устаревшим позициям.

Т. В. Коваль подчеркивает, что «лишь в конце XIX - начале XX вв. русские православные богословы и религиозные философы «серебряного века» стали восстанавливать светлые тона эсхатологизма и, тем самым, оправдывать земной активизм и хозяйственную заботу, пересматривать вопрос о собственности и земных благах. В целом можно сказать, что преобладающими в истории ... были мрачные тона эсхатологии, которая препятствовала развитию хозяйственно-экономической этики» 17 .

В контексте сбережений можно отметить некоторые работы, идущие вразрез с общей тенденцией. Так, уже в «Домострое» 18 Сильвестра (XVIв.) появляется новый идеал - домовитого и рачительного хозяина. Ветхозаветная идея о благосостоянии как Божьем благоволении обретает новое звучание. Примечательно, что в контексте православных ценностей некоторые авторы отмечают: общий духовный уровень при этом резко понижается ${ }^{19}$.

16 Гісторыя палітычнай і прававой думкі Беларусі XVI-XVIII ст.: Хрэстаматыя / Ау̃т.склад. Т.І. Доўнар, Ю.П. Доўнар, Л.Л. Голубева; Пад рэд. Т.І. Доўнар.- Мінск : БДУ, 2004. - С. 103-105.

17 Коваль Т.Б. Личность и собственность в христианстве: Православие. Католицизм. Простентантизм. Сравнительный анализ: дис. ... докт. истор. наук: 07.00.03 / Т.Б. Коваль. - Москва : Ин-т Европы РАН, 2009. - С. 197.

18 Домострой. - СПб. : Наука, 1994. - 89 с.

19 Коваль Т.Б. Личность и собственность в христианстве: Православие. Католицизм. Простентантизм. Сравнительный анализ: дис. ... докт. истор. наук: 07.00.03 / Т.Б. Коваль. - Москва : Ин-т Европы РАН, 2009. - С. 37. 
В эпоху Петра I выходит в свет «Книга о скудости и богатстве» И. Т. Посошкова (1724 г.). Ее автор пропагандирует воздержанность: «Если подданные даром и напрасно ничего не будут тратить, будут жить воздержаннее, ... все обогатятся, а царские сокровища со излишеством наполнятся и ... побор... не морщася, платить будут» 20 .

Вместе с тем, общее негативное отношение к сбережениям в Российской империи сохраняется весь феодальный период. Показательно, что сам термин «частная собственность» не употребляется в России вплоть до конца XVIII в. (правление Екатерины II) $)^{21}$.

Ситуация меняется с развитием рыночных отношений. В отличие от Европы, в России этот процесс начинается позднее: с XVIII в. и особенно активно в XIX - XX вв. Постепенно сберегательное дело в Российской империи становится важным объектом государственной экономической политики.

В среде религиозных мыслителей, юристов и общественных деятелей этого периода выдвигается и со временем получает широкое распространение тезис о важности экономического аспекта человеческой жизни. С. Н. Булгаков, Н. А. Бердяев, С. Л. Франк и др. считают собственность необходимым условием реализации свободы, а «одухотворенные» человеческим трудом вещи продолжением личности. Так, Н. А. Бердяев называет собственность духовным началом, предполагающим не только потребление материальных благ, но и более устойчивую и преемственную жизнь личности, в первую очередь духовную, в семье и роде, помогающую ей совершать «акты, преодолевающие быстротечное время» (Философия неравенства. Письма к недругам по социальной философии. Письмо двенадизатое. О хозяйстве 22$)$.

П. Б. Струве в своем труде «Отечество и собственность» связывает понятие собственности с патриотизмом, чувством Отечества, так как по первоначальному смыслу слово «патриот» обозначает человека, который прочно стоит на унаследованной «родовой земле». 23 Это созвучно идеям немецкого автора Т. Ахелиса, который в своей «Этике» подчеркивает: «Патриотизм является органическим продуктом перехода общества от кочевой

${ }^{20}$ Посошков И.Т. Книга о скудости и богатстве / И.Т. Посошков. - М. : АН СССР, 1951. - С. 13-14.

${ }^{21}$ Шейнин Л.Б. Как в российском праве появилось дремлющее право на землю / Л.Б. Шейнин // История государства и права. - 2014. - № 14. - С. 17.

22 Цит. по: Русская фрилософия собственности, XVIII-XX вb. / Авт. -сост. К. Исупов, И. Савкин. - СПб. : Ганза, 1993. С. 267.

23 Там же. С. 269. 
жизни к оседлости, появления частной собственности» 24.

Рачительный, домовитый хозяин выступает ориентиром в процессе социально-экономического реформирования конца XIX - начала XX вв. При этом западная «философия скупости» так и не перенимается восточноевропейскими авторами. Она воспринимается как нечто чуждое и недуховное. В. С. Соловьев подчеркивает: «Собственность сама по себе не имеет ничего абсолютного. Это ... относительный и обусловленный принцип, который должен подчиняться принципу абсолютному - принципу нравственной личности» 25 .

Стремление сохранить духовную доминанту в любой деятельности, свойственное многим мыслителям анализируемого периода, не всегда соответствует динамичному развитию экономических отношений. Однако сберегательная культура в данное время совершенствуется очень активно. Этому в значительной степени способствовует институциональное и правовое становление сберегательного дела.

В XVIII в. начинает зарождаться банковская система. Государственная власть становится инициатором создания депозитных банков, своеобразного аналога западноевропейских сберегательных касс, «для основных правоспособных классов и социальных слоев феодальной России - дворян, купцов, чиновников, духовенства» 26 .

B XIX в., также через прямое государственное предписание, появляются сберегательные кассы с целью «развития благосостояния сельских обывателей, как материального, так и нравственного, препятствия затруднения в приискании денег для удовлетворения разных срочных платежей в казну или покупки необходимых потребностей по сельскому хозяйству, а равно неимению способов в случае некоторого излишка у поселянина денег сохранить их с выгодой на будущее время» 27 . Основной целью банковских

${ }^{24}$ Ахелис Т. Этика / Т. Ахелис. - СПб. : «Брокгауз-Ефрон», 1906. - С.44.

${ }_{25}^{5}$ Соловьев В.С. О христианском единстве / В.С. Соловьев. - М. : Рудомино, 1994. - С. 149.

26 Абдулкадиров М.Х. Государственная политика России в становлении и развитии сберегательного дела в стране в XIX - начале XX вb. : Исторический аспект исследования : дис. ... канд. истор. наук: 07.00.02 / М.Х. Абдулкадиров. - М. : Российская экономич. Академия им. Г.В.Плеханова, 2000. - С. 242.

27 Цит. по: Белугин Ю.М., Акимов А.Н. Организация сбережений населения в дореволюционной России / Ю.М. Белугин, А.Н. Акимов / / Денъги и кредит. - 1991. № 11. - С. 56-57. 
вкладов признается именно обеспечение сохранности имущества ${ }^{28}$.

Разработка проекта сберегательных касс имеет довольно длительную историю. Считается, что впервые с подобной инициативой выступала уже Екатерина II. Однако серьезная работа началась при Николае I и продолжалась в течение двух десятилетий (20-30-е г. XIX в.). В результате в 1841 г. был принят Устав сберегательных касс, разработанный при участии Е. Ф. Канкрина. Последнего нередко называют родоначальником сберегательного дела в России $^{29}$.

Первые сберегательные кассы учреждаются в Санкт-Петербурге, Москве, Одессе. К 1849 г. кассы работают при 42 из 55 провинциальных приказов, действующих в губернских центрах. Наряду с кассами вкладные операции осуществляют банки, самые мелкие суммы вкладов могут принимать Заемный банк и Приказы общественного призрения.

Во второй половине XIX в. в Российской империи проводятся государственные, экономические, правовые, социальные реформы. Отменяется крепостное право. Изменяется кредитная система. Ликвидируются казенные банки, организуются новые государственные кредитные учреждения, разрешается создавать негосударственные банки.

В 1862 г. реформируется Устав сберкасс. В соответствии с ним кассы должны быть доступны людям недостаточного состояния и служить хранилищами только для самых мелких вкладчиков. В этот период сберкассы передаются в ведение Госбанка. Разрешается организовывать кассы под управлением местных выборных структур при общем наблюдении Правительства. В 80-е гг. XIX в. принимается ряд законодательных актов, в соответствии с которыми разрешается открывать сберкассы в губернских и уездных городах при казначействах (1884 г.), а затем и при почтово-телеграфных учреждениях (1889 г.).

1 июня 1895 г. Николай II утверждает новый устав сберегательных касс, подготовленный министерством финансов при личном участии министра С. Ю. Витте и одобренный Государственным советом. Кассы получают статус государственных. Они открываются при учреждениях Госбанка,

\footnotetext{
${ }^{28}$ Неболсин Г.П. Банки и другия кредитныя установления в России и иностранных земляхъ / Г.П. Неболсин. - СПб. : Тип. Е. Фишера, 1840. - С. 133.

29 Петров Ю.А., Калмыков С.В. Сберегательное дело в России: вехи истории / Ю.А. Петров, С.В. Калмыков. - М. : К.И.Т., 1995. - 364 с. С. 13-14.; Кашин Ю.И. Развитие сберегательной системы в дореволюционной России / Ю.И. Кашин // Банковские услуги. - 2001. - № 2. - С. 19.
} 
казначействах, таможнях и других учреждениях ведомства Министерства финансов, а также при общественных, государственных и частных учреждениях распоряжением министра финансов. Развитие сберкасс в этот период обусловлено также предоставлением новых услуг (прием вкладов на имя детей, перевод средств из одной кассы в другую и т. п.). Вкладчиками сберкасс становятся миллионы жителей Российской империи.

В начале XX в. общей тенденцией развития сберегательного дела в России, как и в Западной Европе, становится постепенное превращение сберегательных касс в кредитные учреждения универсального типа. На основании Закона от 30 мая 1905 г. «О введении страхования жизни при посредничестве сберегательных касс» наряду с вкладными и кредитными операциями сберегательные кассы принимают на себя функции страхования жизни вкладчиков.

В анализируемый период сберегательные кассы открываются на судах военного флота, при казённых винных складах, таможнях, управлениях железных дорог. Получают распространение волостные сберегательные кассы. Государственные сберкассы создаются в местах базаров и ярмарок на время их работы ${ }^{30}$.

Сберегательные кассы появляются при начальных и средних школах. Предполагается, что они должны формировать у населения основы бережливости и сберегательной культуры. К 1914 г. в целом по России действует около 2500 школьных касс (в том числе, 359 - при средних учебных заведениях, 1385 - при низших), с 41200 вкладчиками-учениками 31 . Общий объем операций сберегательных касс стремительно возрастает ${ }^{32}$.

В 1916 г., на основании Высочайшего разрешения, сотрудники Особенной канцелярии по кредитной части и Управления государственными сберегательными кассами командируются в США для открытия отделений русских государственных сберегательных касс в центрах наибольшего

30 Шерстнева Н.П. История сберегательного дела в России в XVIII - XX веках и роль частных вкладов в формировании пассивной базы банков : автореф. дис. ... канд. экон. наук: 08.00.01 / Н.П. Шерстнева. - СПб. : Санкт-Петербургск. гос.ун-т экон. и финансов, 2005. - C. 13.

31 Бойко П.С. Сберегательное дело в досоветской России (K 170-летию Сберегательного банка России) / П.С. Бойко // Экономический журнал. - 2011. - № 23. - C. 139-148.

32 Петров Ю.А. Сберегательные кассы и проблемы государственного долга России на рубеже XIX-XX в. / Ю.А. Петров // Экономическая история. Обозрение / под ред. Л.И.Бородкина. - М. : Изд-во МГУ, 2005. - Вып. 10. - С. 196. 
скопления выходцев из России. Такие кассы образованы в Нью-Йорке, Чикаго и Питсбурге. Ставится вопрос об открытии русских сберегательных касс в Канаде, Аргентине, Бразилии и Китае.

Реализации этих амбициозных планов помешали революционные события. В 1917 г. сберегательная система Российской империи, как и сама империя, перестала существовать. Однако в целом можно утверждать, что с зарождением капитализма и активным становлением права частной собственности сбережения обретают инвестиционный аспект и отношение к ним меняется в положительную сторону. На Западе это происходит в более ранний период, на Востоке - позднее. Белорусская и украинская сберегательно-правовые культуры впитали как западные, так и восточные традиции (в широком понимании). С присоединением земель к Российской империи доминировать начинает восточнохристианский подход. Активное развитие сбережений начинается в XIX в. в связи с институциональным и правовым становлением сберегательного дела.

Dr. habil. Julia Gavrilchenko (Minsk, Belarus)

Axiological and institutional development of savings and the problem of private property in the formation of a market economy

Improving the legal regulation of adaptive sports movement in the Republic of Belarus

The article is devoted to the constitution of a scientific discussion about the western and eastern vectors of the development of the saving culture - the most important aspect of the legal intersection of economic and geographical problems. The question of the origin and establishment of the institution of savings banks in the space of the former Russian Empire is being investigated. The specificity of the UkrainianBelarusian legal understanding of property is considered.

Key words: Axiology of Law, Ethics of Self-restraint, Ukrainian-Belarusian Complex of Traditions, Saving Legal Culture, Savings Banks, Banking.

Профессор Юлия Гаврильченко (Минск, Беларусь)

Аксиологически-институциональное развитие сбережений и проблема частной собственности в условиях становления рыночной экономики Статья посвящена конституированию научной дискуссии о западном и восточном векторах развития сберегательно-правовой культуры - важнейшему аспекту юридического пересечения экономической и географической проблематики. Исследуется вопрос о зарождении и установлении института 
сберегательных касс на пространстве бывшей Российской империи. Рассматривается специфика украинско-белорусского правопонимания собственности.

Ключевые слова: аксиология права, этика самоограничения, украинскобелорусский комплекс традиций, сберегательно-правовая культура, сберегательные кассы, банковское дело.

Професор Юлія Гаврильченко (Мінськ, Білорусь)

Аксіологічно-інституційний розвиток заощаджень і проблема приватної власності в умовах становлення ринкової економіки

Стаття присвячена конституюванню наукової дискусії про західний і східний вектори розвитку ощадно-правової культури - найважливіший аспект юридичного осмислення міждисциплінарної економіко-географічної проблематики. Досліджується питання про зародження і встановлення інституту ощадних кас на просторах колишньої Російської імперії. Розглядається специфіка українсько-білоруського праворозуміння власності.

Ключові слова: аксіологія права, етика самообмеження, українськобілоруський комплекс традицій, ощадно-правова культура, ощадні каси, банківська справа.

* Гаврильченко Юлия Петровна - доктор юридических наук, профессор, профессор кафедры финансового права и правового регулирования хозяйственной деятельности юридического факультета Белорусского государственного университета в Минске. E-mail: yuliyadovnar@rambler.ru. 